\title{
Sociocultural significance of the endangered Hawaiian monk seal and the human dimensions of conservation planning
}

\author{
John N. Kittinger ${ }^{1,3, *}$, Trisann Māhealani Bambico' ${ }^{1}$, Trisha Kehaulani Watson ${ }^{2}$, \\ Edward W. Glazier ${ }^{1}$
}

${ }^{1}$ Impact Assessment, Inc., Pacific Islands Office, 367-C Kapaloala Place, Honolulu, Hawaii 96813, USA

${ }^{2}$ Honua Consulting, PO Box 61395, Honolulu, Hawaii 96839, USA

${ }^{3}$ Present address: Stanford University, Center for Ocean Solutions, Woods Institute for the Environment, 99 Pacific Street, Suite 155A, Monterey, California 93940, USA

\begin{abstract}
The Hawaiian monk seal Monachus schauinslandi is Critically Endangered, but relatively little is known about the sociocultural significance of the species in Native Hawaiian communities. An accurate assessment of historical and modern sociocultural values and perceptions is needed to inform conservation and recovery planning for the species, particularly since the species is not universally well-regarded by ocean users. We conducted extensive archival research and oral history interviews to characterize past and current human-monk seal relationships in the Hawaiian archipelago. We report heterogeneity in both historical and contemporary cultural associations for monk seals, which appear to be related to place-specific histories and specific stakeholder groups. We introduce the concept of 'cultural endemism' to characterize this pattern of sociocultural heterogeneity, and discuss the relevance of shifting baselines, species recovery, and sociocultural information to conservation planning. We focus on participatory conservation planning approaches as being potentially useful in reducing human-wildlife conflicts and developing collaborative stewardship for better conservation success.
\end{abstract}

KEY WORDS: Endangered species · Wildlife conflict · Cultural endemism · Historical ecology · Human-environment interactions $\cdot$ Shifting baselines $\cdot$ Participatory management

\section{INTRODUCTION}

Wildlife conservation programs often have to deal with the complexities of human conflicts with species that are targeted for protection and recovery. Wildlife that threatens human property, livelihoods, or activities can result in retaliatory actions that present challenges to conservation actions and threaten the survival of endangered species (Treves et al. 2009). Too often, sound conservation plans can falter because they fail to address the diverse social factors and conditions that shape human interactions with species and the environments they occupy (Treves et al.
2009, Lovecraft \& Meek 2011). These human dimensions include economic, technological, demographic, institutional, perceptual and political factors, which can affect the prospects for successful species recovery and stewardship (Bath 1998, Jacobson \& Duff 1998). Despite this, most endangered species programs focus primarily on the biological aspects of endangered species, and, in comparison, relatively little research is directed toward the human dimensions of endangered species, which are critical for effective conservation planning and species recovery programs (Kellert 1985, 1986, Jacobson \& Duff 1998, Lovecraft \& Meek 2011). 
Social and perceptual factors are especially important in understanding how human societies interact with endangered species and their habitats in places characterized by human-wildlife conflict (Clark et al. 1994, Tarrant et al. 1997, Bentrupperbaumer et al. 2006). Human-wildlife conflicts can develop through a myriad of different pathways, but are based in part on the underlying social values, norms and perceptions that structure human-environmental interactions. Stakeholders may exhibit a range of values for endangered wildlife (Kellert 1985, Treves 2008), and these values, like other social phenomena, are not static but evolve through time.

Human values and perceptions are strongly influenced by historical context, sociocultural setting and knowledge systems that develop in a place-based manner. This is particularly true in the Pacific Islands and other similar settings where indigenous cultures developed in-depth traditional ecological knowledge systems and close relationships with the environments that provided goods, values and services upon which they depended. In Polynesian communities, the values and perceptions of species and the ecosystems in which they are embedded are strongly influenced by traditional sociocultural practices, uses and knowledge systems. Ecosystem constituents are primarily viewed, not as independent units, but as part of an interconnected system in which humans are embedded as natural constituents (Handy \& Pūkui 1972, Jokiel et al. 2011).

Species can, however, take on unique meanings and significance, which in turn mediate the way human societies interact with the species and its associated habitats. For example, many Pacific Islander cultures developed customary restrictions on use of sea turtles, which served to limit harvest and conserve the species (Allen 2007, Rudrud 2010). Sociocultural values and perceptions have evolved as island communities have been subjected to changing socioeconomic, political and institutional conditions, and as a result there is a need to understand how past relationships with endangered species affect current and future conservation efforts. This is particularly important given the diversity of stakeholders in coastal zones, many of whom may exhibit different perspectives on wildlife. Understanding the sociocultural dimensions of endangered species holds promise for effectively engaging stakeholders and reducing conflicts that can pose a threat to effective conservation.

The purpose of this article is to characterize the historical and contemporary significance of monk seals in Native Hawaiian communities and discuss the rel- evance of sociocultural data to current conservation challenges for endangered species recovery.

The Hawaiian monk seal is classified as 'Critically Endangered' (IUCN 2011) and gained protection under the United States Endangered Species Act in 1976. In the past few decades, monk seal populations have been increasing on the main Hawaiian Islands. This has led to increased conflicts with ocean users particularly fishers - which have occasionally resulted in intentional killings of monk seals. We provide a background for our case study and the social-ecological context of human-monk seal interactions in Hawai'i. We then describe our methodology and present the detailed results of our research, and finally, we discuss the significance of our findings and how the sociocultural significance of endangered species can be applied to conservation planning. We introduce the concept of 'cultural endemism' to characterize the place-specific context and sociocultural factors that influence social relationships with natural resources, and review the relevance of shifting baselines to species recovery. We conclude by discussing the potential of participatory approaches to conservation planning to reduce human-wildlife conflict and increase the efficacy of species conservation through collaborative stewardship.

\section{BACKGROUND}

The Hawaiian Islands were among the last places on Earth to be colonized by humans. Voyaging Polynesians arrived in Hawai'i in approximately AD 1250 to 1290 (Wilmshurst et al. 2011); thereafter, they established complex societies and resource production systems that supported a dense human population with complex sociopolitical systems (Kirch 1985, Vitousek et al. 2004). Polynesians introduced exotic species and utilized both terrestrial and marine ecosystems for basic subsistence, altering endemic populations of fauna and flora and transforming natural ecosystems into cultural land- and seascapes in the process (Burney et al. 2001, Maly 2001, Kaneshiro et al. 2005, Athens 2009, Kittinger et al. 2011).

Hawaiian monk seals Monachus schauinslandi are estimated to have inhabited the Hawaiian archipelago for approximately 14 million $\mathrm{yr}_{\text {; }}$ thus, the species has adapted to long-term geological changes in the archipelago (Ragen 1999, Ragen \& Lavigne 1999). Monk seal habitats include shallow water reef habitat for pupping, weaning and foraging, sandy beach areas for hauling out, and deeper reef areas for foraging (Kenyon \& Rice 1959, NMFS 2007). Hawaiian 
monk seals are apex predators in coral reef environments, but exhibit extreme sensitivity and vulnerability to human stressors, which renders the species vulnerable to local extirpation and extinction (Kenyon 1972, 1980, Ragen 1999, Ragen \& Lavigne 1999, Gilmartin 2002). The Hawaiian monk seal population is currently comprised of approximately 1200 individuals and is declining at a rate of approximately $4 \% \mathrm{yr}^{-1}$ (Antonelis et al. 2006, NMFS 2007).

Currently, the majority of Hawaiian monk seals are found in the remote and primarily uninhabited northwestern Hawaiian Islands (NWHI), but a smaller population is growing in the main Hawaiian Islands (MHI). Increased juvenile survivorship in the MHI versus the NWHI is likely due to the difference in interspecific competition, as large predators such as jacks and sharks are rare in the MHI and more abundant in the NWHI, where food limitation has limited survivorship (Baker \& Johanos 2004, Baker et al. 2011). Monk seals in the MHI are threatened by human disturbances, and this is where the majority of human-monk seal conflicts have occurred.

Monk seal recovery is not universally supported in Hawaiian communities, and some ocean users view the species as a nuisance or threat. For example, $>6$ monk seals were recently killed by apparent intentional shooting, and foul play cannot be ruled out in the recent deaths of at least 5 other seals (Levine 2009, Anonymous 2010, Osher 2011, McAvoy 2012, Nasako 2012). The most commonly cited source of human-monk seal conflict is negative interactions with fishers. Common interactions include seals taking fish off lines or out of fishers' nets, but increasingly seals are interacting with boats and fishermen directly — in some cases, fishermen have been bitten by monk seals. These conflicts are a major concern for long-term conservation and recovery planning for the species, particularly considering the continuing decline in NWHI populations and increase in monk seal numbers in the populated MHI (Baker et al. 2011).

\section{METHODS}

We employed 2 primary methods to characterize the sociocultural significance of the Hawaiian monk seal: (1) archival research and document analysis and (2) ethnographic research and oral history interviews with Native Hawaiian community members, elders (kūpuna) and cultural experts and practitioners. Our archival research efforts targeted historical and contemporary information about human-monk seal interactions and cultural significance of the species in documents retrieved from various institutional and online repositories. Our research targeted both English-language and Hawaiian-language sources, including the extensive collection of archived Hawaiian-language newspapers and sources in existing compilations of historical documents (Balazs \& Whittow 1979, Hiruki \& Ragen 1992). English-language archival sources included:

(1) Published archaeological reports, containing zooarchaeological faunal assemblages and midden contents;

(2) Archival and historical documents containing anecdotal or descriptive data (e.g. reports from naturalists, missionaries and explorers; whaler's logbooks; historical newspapers);

(3) Published ethnographic information (e.g. recorded oral histories; interviews with elders); and

(4) Contemporary ecological data (e.g. population studies; genetic studies).

Our research also involved an exhaustive search in Native Hawaiian language newspapers for references to the Hawaiian monk seal. Newspaper searches were conducted in online databases of published and searchable newspapers (Ulukau 2003, Alu Like et al. 2006). As part of the search process, a list of Hawaiian language terms for the monk seal was developed and the etymology of these terms was investigated. All references were translated into English, categorized in terms of the type of account (e.g. fishing story, legend, chant, prayers, etc.) and then analyzed, resulting in an interpretation of each account and its meaning or significance in Native Hawaiian culture.

We also conducted unstructured ethnographic and oral history interviews with 30 Native Hawaiian community members, cultural practitioners and kūpuna. We targeted individuals known to possess extensive knowledge of endemic Hawaiian species, marine and coastal environments, and historic and contemporary cultural practices or knowledge that may have some association with monk seals. Interviews focused on cultural connections with the monk seal among Native Hawaiian communities, as determined through respondents' oral testimonies or reported statements about past and current relationships with the species. Respondents were identified through a chain referral, or 'snowballing' sampling process (Penrod et al. 2003, Bernard 2006), and we purposively selected individuals who were particularly knowledgeable of, or experienced with, monk seals or Native Hawaiian cultural knowledge systems (cf. Maxwell 1997). These methodologies are 
commonly employed in social science research (Bernard 2006), including studies on marine resource use (e.g. Aswani \& Hamilton 2004, Cinner et al. 2009).

Interviewees were comprised of respondents that exhibited the broad and sometimes conflicting range of views on the monk seal that existed in the Native Hawaiian community at the time the research was conducted. This purposive sampling of respondents allowed us to characterize a multiplicity of perspectives among community members, which can reveal different values and information that exist in different social groups and knowledge systems (Romney et al. 1986, Shackeroff et al. 2011). Interview methods followed existing standards in social science research (Kvale 1996, Seidman 1998, Bernard 2006), and interviews were conducted in a manner that was culturally appropriate and respected the traditional ecological knowledge systems of the respondents (Shackeroff \& Campbell 2007).

Interviews were audio- or video-recorded, and, together with notes taken during the interviews, responses were coded into topical categories. We relied on an iterative methodology to describe, categorize and interpret our qualitative interview data an approach that is utilized commonly in the grounded theory approach (Glaser \& Strauss 1967, Schatzman 1991, Thomas \& James 2006). Our methods focused primarily on an inductive analysis to systematically determine patterns in our respondents' narratives rather than on theory generation, and the iterative methodology employed was designed to establish rigor in the analysis of our qualitative information (Baxter \& Eyles 1997, Barbour 2001).

In addition to interviews, we also sought other evidence of monk seals in Native Hawaiian cultural knowledge, including historical accounts, chants (mele), prayers (oli), existing oral histories (e.g. Maly \& Maly 2004), place names, and other traditional and customary knowledge forms. We also engaged in other ethnographic research methods, including site visits and participant observation in Hawaiian communities and places with names potentially referencing monk seals.

\section{RESULTS}

Our research uncovered a diversity of information about historical and contemporary relationships between Hawaiian communities and the monk seal Monachus schauinslandi. Below, we discuss our findings uncovered through different sources and re- search efforts. Additional material is included in the supplement at www.int-res.com/articles/suppl/n017 p139_supp.pdf. It should be noted at the outset that although our research included a comprehensive search of traditional cultural sources, additional information may still be waiting to be discovered in extant Hawaiian literature and cultural knowledge forms.

\section{English-language archival sources}

The results of our archival search in English language sources have been published elsewhere (Watson et al. 2011), but a brief overview of these findings and an additional description is provided here for context and comparison with other research results. Our research in this diverse set of sources suggests that seal populations were probably locally extirpated in the MHI within the first century after Polynesian settlement ( AD 1250 to 1350). Pre-human seal populations probably never exceeded 15000 individuals, which constitutes a small and vulnerable population for a large mammal (Watson et al. 2011). Remains of monk seals in archaeological deposits are limited to just a few sites that primarily date to the historic period (Fig. 1), suggesting that monk seals were opportunistically taken by Native Hawaiian hunters. Though several theories still exist, the most likely explanation based on the available evidence is that seal populations were probably rapidly diminished in Hawaiian prehistory by human hunters and harassment by their commensal mammals (particularly dogs Canis familiaris).

The first few decades after western contact (AD 1778 to 1830 ) - before the Hawaiian language was translated into a written form - are among the least well understood periods in Hawaiian history. During this period, whaling, sealing and other trading vessels increasingly frequented the archipelago, and trade between Hawaiian communities and foreigners intensified (Kamakau 1992, ' '⿳亠口冋'十 1993). Hawaiians became involved in the seal trade as early as 1811 (' $\overline{\mathrm{I}}$ ' $\overline{1}$ 1993), and were conscripted as sailors on whaling and sealing vessels by Hawaiian monarchs (Kuykendall 1938, 1957, Naughton 1983, Beechert 1991). This period also witnessed major changes in the relationship between commoners and the land, including the abolishment of the Native Hawaiian religious system (Seaton 1974, Ralston 1984) that included traditional restrictions on some marine species (but not monk seals) (Beckley 1883, Titcomb 1972).

Despite several detailed English-language accounts of the Hawaiian Islands that date from this period, no 


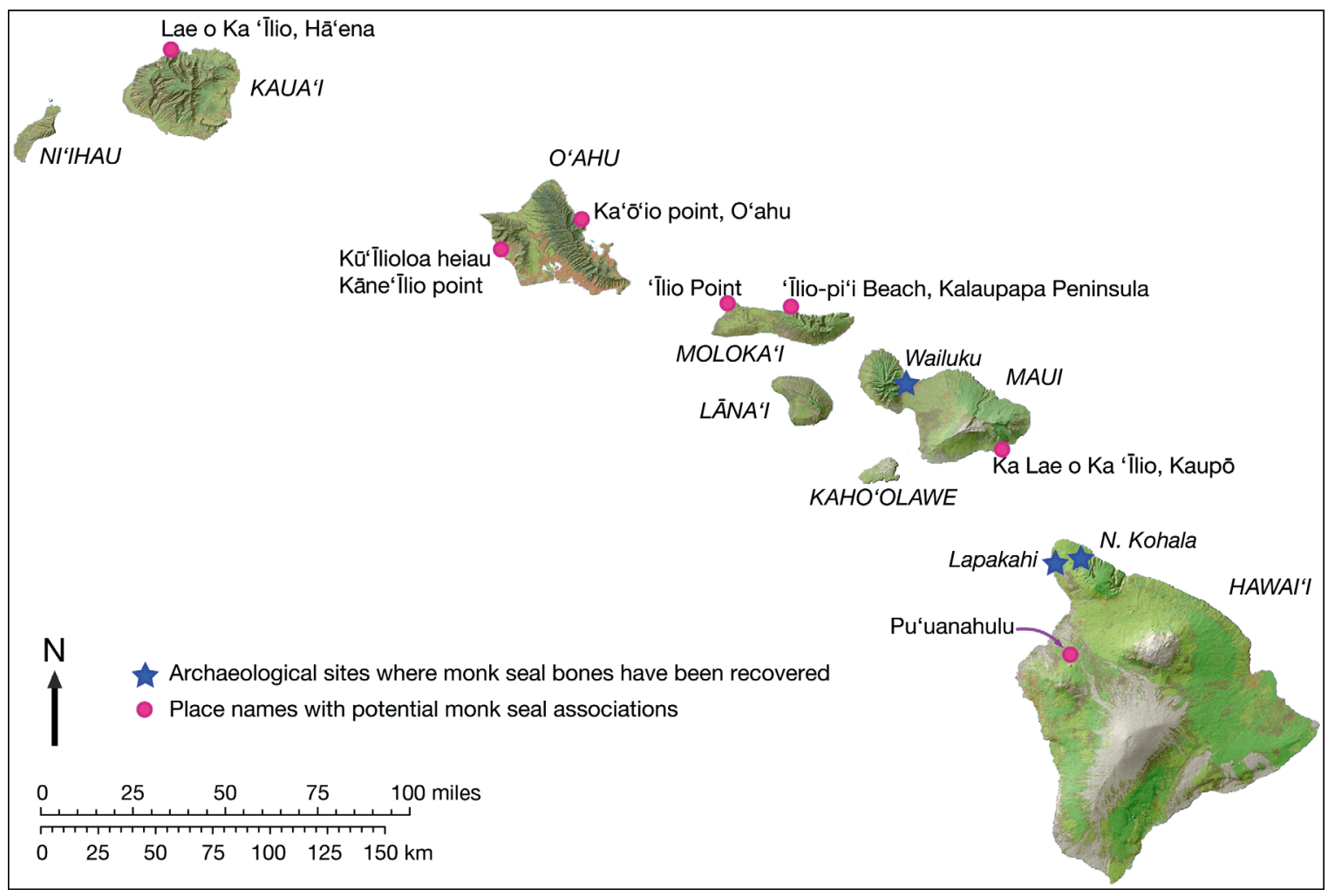

Fig. 1. Map of the main Hawaiian Islands, showing archaeological sites where monk seal Monachus schauinslandi bones have been recovered and places with names that potentially reference monk seals. Archaeological data from Rosendahl (1994), Office of Hawaiian Affairs (2010) and R. Rechtman (pers. comm.)

descriptions of monk seals were recorded in the MHI (see the supplement, Section 5). This strongly suggests rarity, particularly given that many early descriptions come from whalers and sealers that would have been interested in harvesting seals for their oil, or from explorers and naturalists that described other social and environmental contexts in great detail. Of these early descriptions, however, it remains difficult to disentangle which sealing cargoes were derived from ventures outside of Hawaiian waters (e.g. Alaska, the Pacific Northwest and the California coast) and which may have been comprised of monk seal populations from Hawaiian waters (Kuykendall 1929). When seals were discovered in the mid-19th century in the remote and uninhabited northwestern Hawaiian Islands, several sealing voyages were undertaken (Cobb 1905). Seals were also taken opportunistically in the NWHI during this period by visiting ships, including ones bearing Hawaiian monarchs (e.g. Anonymous 1857). Few monk seals survived the sealing ventures of the 19th century, resulting in near-extinction and extreme rarity throughout the archipelago in the early 20th century (Hiruki \& Ragen 1992).

\section{Hawaiian-language newspapers}

The Hawaiian-language newspapers are an unparalleled resource in the Pacific in terms of the volume of material and richness of description (Nogelmeier 2010). Only $\sim 10 \%$ of published newspapers have been electronically scanned and made searchable, but this constitutes a representative sample (P. Nogelmeier pers. comm.). Our search consisted of identifying Hawaiian terms for monk seals and the etymology of these terms. Next, we located articles containing these terms in online databases of digitized Hawaiian-language newspapers (Ulukau 2003, Alu Like et al. 2006) and translated these accounts (see the supplement, Section 7).

We discovered many terms for monk seals in our search in Hawaiian-language dictionaries, archives and newspapers (Table 1). The most commonly used term, 'illioholoikauaua, roughly translates to 'dog running in the rough [seas]' (Pūkui \& Elbert 1986). Two other commonly referenced terms, 'sila' and 'kila,' are Hawaiian versions of the word seal,' and probably date to the post-contact era. Several previously unknown terms were also discovered, includ- 
Table 1. Native Hawaiian terms for the monk seal Monachus schauinslandi. Definitions and references are provided, including information derived from other archival and interview research efforts on these terms; square brackets indicate implied meaning or additional clarification from accompanying text. For additional information see the supplement, Section 6

\begin{tabular}{|c|c|c|}
\hline Term $^{\mathrm{a}}$ & Definition & Reference / Notes \\
\hline ‘īlioholoikauaua & $\begin{array}{l}\text { Seal, dog running in the roughness } \\
\text { [rough seas] }\end{array}$ & $\begin{array}{l}\text { Pūkui \& Elbert (1986)/Entry does not appear } \\
\text { in the online dictionary (Ulukau 2003) }\end{array}$ \\
\hline 'ioleholoikauaua & A rat running beside the wave & Beckwith (1951) \\
\hline ‘îlioholoikauaua-a-Lono & The dog running at the voice of Lono & $\begin{array}{l}\text { Fornander (1916-1920) (Vol. IV, p. 273)/ } \\
\text { Only known reference }\end{array}$ \\
\hline ‘īlioheleikauaua & The dog running in the waves & Andrade (2008) \\
\hline ‘îlioholoikekai & The dog running in the sea & $\begin{array}{l}\text { Mo'olelo (oral traditions) from kūpuna and } \\
\text { kumu (elders \& teachers) }\end{array}$ \\
\hline ‘aukai & Seafaring & Mo`olelo (oral traditions) from kūpuna \\
\hline holoikauaua & $\begin{array}{l}\text { i'oa Pearl and Hermes Reef [NWHI]. } \\
\text { Literally, [Hawaiian monk seal that] } \\
\text { swims in the rough }\end{array}$ & Kōmike Hua‘ōlelo (2003) \\
\hline hulu & Seal, named for its valuable fur & Pūkui \& Elbert (1971) \\
\hline sila / kila & $\begin{array}{l}\text { Hawaiian versions of the English } \\
\text { word "seal" }\end{array}$ & $\begin{array}{l}\text { Kōmike Hua'ōlelo (2003)/It is probable that use of } \\
\text { this term did not begin until after foreign contact }\end{array}$ \\
\hline ohulu (ō-hū'-lu) & $\begin{array}{l}\text { O, to spear; and hulu, fur or feathers. } \\
\text { A seal hunter }\end{array}$ & $\begin{array}{l}\text { Parker (1922)/Entry does not appear in the online } \\
\text { dictionary (Ulukau 2003) }\end{array}$ \\
\hline he ilio o ke kai & Seal & Andrews (1865) \\
\hline sila pūhuluhulu & Fur seal & Kōmike Hua‘ōlelo (2003) \\
\hline sila Hawai‘i & Hawaiian monk seal & Kōmike Hua‘ōlelo (2003) \\
\hline ‘īliopi‘i & Climbing dog & Hawaiian language newspapers; maps \\
\hline \multicolumn{3}{|c|}{ 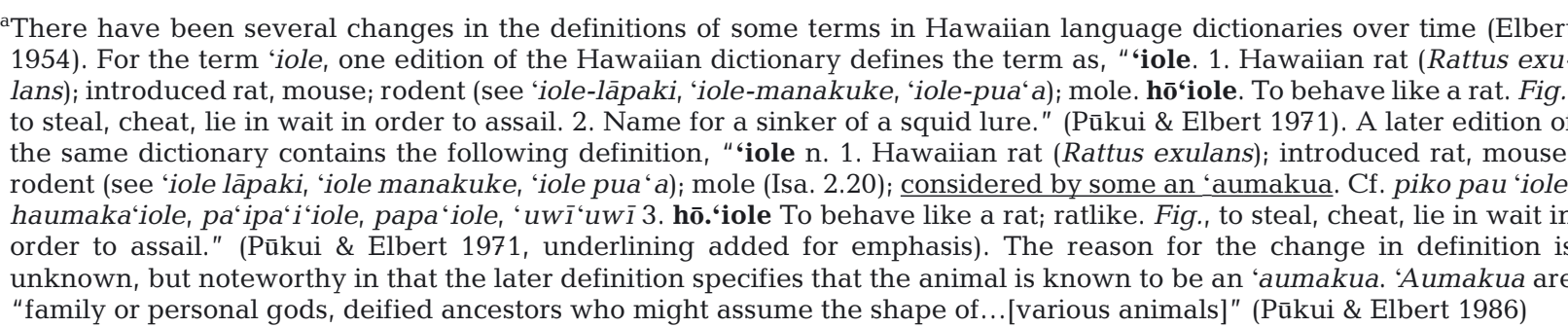 } \\
\hline
\end{tabular}

ing 'hulu,' which is defined in an earlier dictionary as 'seal, named for its valuable fur' (Pūkui \& Elbert 1971). This term was also used by some respondents in interviews to reference monk seals (see video by $\mathrm{T}$. K. Watson at www.nameahulu.org). Another term, 'ohulu,' is defined as a seal hunter (Parker 1922). The term 'palaoa' commonly references whales or other cetaceans, but in a traditional chant (the Kumulipo), it may also apply to other marine mammals including monk seals (Nerveza 2010). Some respondents knew of other names for the monk seal, but declined to provide the names because of worries about how the names would be used.

Most references to monk seals in Hawaiian-language newspapers date to the mid-to late 19th century (see the supplement, Section 8), and references are primarily used in a neutral tone with little description. For example, writers used the term 'îlioholo-ikauaua to reference seals in translations of
English works, and other descriptions use the same term to describe seals on sealing voyages to Alaska and the United States Pacific northwest, on which Native Hawaiians served as crew members. For example, one writer describes a trip to the Arctic where the crew were kept warm by 'the pelt of the 'ilio-holo-i-ka-uaua and the other slippery, furry animals,' while another writer describes the arctic as 'Just snow is what is seen there, no plants; the polar bear is still important, with the 'illioholoikauaua, and the sea elephants.' Other writers used the term 'ìliokai or 'îlio o kai (seadog) and sila (seal) in descriptions of sealing expeditions. These accounts provide little information about the cultural relationship with monk seals but do provide evidence that the name was known to Hawaiian writers during a time when monk seals were rare in the Hawaiian Islands. Other references are more telling of cultural relationships, and several contain negative connota- 
tions. For example, one writer implores fellow Hawaiians not to 'slacken in their moral resolve like the 'illioholoikauaua,' and another writer uses the term loosely as an insult (see the supplement, Section 7). These references provide some evidence that the monk seal was not viewed in a positive manner, but the context does not provide enough description in order to determine why these views were held.

The Hawaiian-language newspapers also provide some evidence that monk seals were harvested and consumed as part of customary practice. For example, one writer writes in a story 'What are the things you think we eat here? Turtle liver, shark fin, and the broiled meat of the 'illioholoikauaua.' Another writer suggests that monk seal furs were collected as part of customary tribute to land managers (Konohiki), writing, 'and then, they lay down these things the Konohiki (land manager) requested: pig, dog, cloth, fiber, fur ['o ka hulu], fishing net, everything. These are the goods that we exhibited in ancient days' (see the supplement, Section 7). These descriptions, though limited, suggest that monk seals were traditionally harvested for their meat and fur.

\section{Traditional cultural sources}

In addition to archival and interview research, other sources of cultural knowledge were accessed and reviewed to ascertain information about Hawaiian monk seals. These sources included mele (songs), oli (chants), mo'olelo (oral tradition), and other traditional knowledge forms. One such source is the Kumulipo, a detailed chant that chronicles the creation story, geneaology and mythology of ancient Hawai'i (Beckwith 1951). Previously it was not believed that any references to the monk seal were found in the Kumulipo, but the term 'ioleholoikauaua' in one section may reference the Hawaiian monk seal (see the supplement, Section 2). The description of the ioleholoikauaua as 'a rat running beside the wave,' is reminiscent of monk seals, and the description of the monk seal in this section of the Kumulipo is also consistent with other descriptions and perceptions of monk seal behavior found in Hawaiian-language sources.

The monk seal is also mentioned in the mo'olelo (oral tradition) about the Legend of Hawai'i-loa. In this story, the monk seal is described as 'illioholoikauaua-a-Lono, and is associated with the Hawaiian god Lono:

After Light had been created or brought forth from the $P o$ [the darkness or chaos] the gods looked upon the empty space [ka lewa] and there was no place to dwell in. They then created the heavens for themselves. Three heavens did they create or call into existence by their word of command. The uppermost heaven was called 'Lani-Makua,' the one next below was called 'he Lani o Ku,' and the lowest was called 'he Lani o Lono.'

The first man, generally called Kumu Honua, had a number of names - already mentioned; he was a tall, handsome, majestic looking person, and so was his wife. He was along upon the land for about one century [kipaelui or kihipea] before his wife Lalo Honua was created.

Among the animals enumerated in the legend as dwelling in peace and comfort with Kumu Honua in Kalani i Hauola were:

Ka puaa nui Hihimanu a Kane [the large Hihimanu hog of Kane]; ka ilio nui niho oi a Kane [the large sharptoothed dog of Kane]; ka ilio holo i ka uaua a Lono [the dog running at the voice of Lono]; ka puaa maoli [the common hog]; ka ilio alii a Kane [the royal dog of Kane]; na moo [lizards]... (Fornander 1916-1920, see the supplement, Section 3; underlining added for emphasis).

This reference is the only known description of the linkage between the god Lono and the monk seal and the only known account of the term 'ka-ilio-holo-i-kauaua-a-Lono.' The association with Lono is also interesting because dogs are typically associated with the god Kane, and many other ocean animals are associated with the god Kanaloa. Additional information is available in Sections 2 to 4 of the supplement.

\section{Hawaiian place names}

Hawaiian place names serve a variety of functions but commonly convey cultural information and associations with geographical features (Pūkui et al. 1974). Place names are often understood, interpreted and perpetuated within traditional mo'olelo that developed in a place-based manner. We performed a search through cartographic and archival sources to identify places in the Hawaiian Islands that potentially reference monk seals. We also undertook several site visits at places believed to be named for monk seals, and obtained additional information about these place names in interviews with local residents and through personal observations.

We identified several sites in the Hawaiian archipelago with names that likely reference the Hawaiian monk seal and many other sites with names warranting more investigation (Fig. 1, Table 2). Two sites have historical associations with monk seals, including a small cape and bay on the rugged Kalaupapa peninsula of Moloka'i. The historical place name 'İlio-pi'i is translated literally as 'climbing dog' (Table 2); this seems appropriate, as monk seals commonly pup on beaches in this area in modern times. 
Table 2. Place names with potential references to monk seals Monachus schauinslandi in the Hawaiian archipelago. Lit: literally

\begin{tabular}{|c|c|c|}
\hline $\begin{array}{l}\text { Place name/ } \\
\text { District, island }\end{array}$ & Notes and definition & Source \\
\hline $\begin{array}{l}\text { ‘Īlio-pi‘i Beacha/ } \\
\text { Kalaupapa, Moloka‘i }\end{array}$ & $\begin{array}{l}\text { Cape and bay, Ka-laupapa peninsula, north central Moloka'i. } \\
\text { Perhaps lit., 'climbing dog' }\end{array}$ & Pūkui et al. (1974) \\
\hline \multirow[t]{2}{*}{ ‘Īlio Point/NW Moloka‘i } & $\begin{array}{l}\text { Point and quadrangle, West Moloka'i, 'dog point' or 'the headland of } \\
\text { the dog' }\end{array}$ & Pūkui et al. (1974) \\
\hline & $\begin{array}{l}\text { The red dog of 'Īlio Point, the shark god Kainalu would take the form of } \\
\text { a dog every fifth year to pay homage to his deceased ancestors on land }\end{array}$ & Ne \& Cronin (1992) \\
\hline Lae o Ka ‘'̄lio / & 'The headland of the dog' or 'the cape of the dog' & Pūkui et al. (1974) \\
\hline Halele’a, Kaua‘i & $\begin{array}{l}\text { Refers to the endangered Hawaiian monk seal known to Hawaiians } \\
\text { as 'illio hele i ka uaua (dog running in the rough seas) }\end{array}$ & Andrade (2008) \\
\hline $\begin{array}{l}\text { Ka-lae-o-ka-'īlio/ } \\
\text { Kaupō, Maui }\end{array}$ & $\begin{array}{l}\text { Points at Kona, Hawai'i, Kau-pō, Maui, northwest Moloka'i (also called } \\
\text { 'îlio and Ka-'īlio). Lit., 'the cape of the dog' }\end{array}$ & Pūkui et al. (1974) \\
\hline $\begin{array}{l}\text { Pu'uanahulu, } \\
\text { Ka-lae-o-ka-'īlio/ } \\
\text { Kona, Hawai'i }\end{array}$ & $\begin{array}{l}\text { Hill and land sections, Kai-lua, Pua-kō, Wa-ki‘i, and Ka-'ohe.'Lit., } \\
\text { ten-day hill. (Perhaps named for a supernatural dog of that name; } \\
\text { see Ka-lae-o-ka-'ilio. In some accounts, Anahulu was a priestess; at } \\
\text { the Kona Point in a sea pool is the body of Anahulu, a supernatural } \\
\text { dog that was changed to stone by Pele) }\end{array}$ & Pūkui et al. (1974) \\
\hline $\begin{array}{l}\text { Kū‘īlioloa heiau, } \\
\text { Kāne`īlio Point/ } \\
\text { Wai`ānae, O`ahu }\end{array}$ & $\begin{array}{l}\text { Heiau at tip of Kāne‘īlio Pt., Wai-‘anae qd., O‘ahu, named for a } \\
\text { legendary dog who protected travelers; later the qualities of a bad } \\
\text { dog were unfairly attributed to him. In one story he is defeated by } \\
\text { Kama-pua‘ā. Lit., long dog Kū }\end{array}$ & Pūkui et al. (1974) \\
\hline \multirow[t]{2}{*}{$\begin{array}{l}\text { Ka‘o ‘io Point/ } \\
\text { Ko‘olau Poko \& } \\
\text { Ko‘olau Loa, O‘ahu }\end{array}$} & $\begin{array}{l}\text { Same as Ka-lae-o-ka-'o`'io: point and beach park, also called Ka-lae-‘'o‘io, } \\
\text { at Kua-loa, O‘ahu, the boundary point between Ko'olau Poko and } \\
\text { Ko'olau Loa. Lit., the cape of the bonefish; }\end{array}$ & Pūkui et al. (1974) \\
\hline & $\begin{array}{l}\text { Place of residence of the 'īlio hā of Kāne, named Kauhike 'īmakaokalani... } \\
\text { 'ịlio hā is like ...an oversized, hulking dog, ... huge, heavy, plump, and } \\
\text { fleshy. But this dog-uncle of ours you see there has the body of a } \\
\text { massive dog, and the largest expanse of his fur is on his head and neck } \\
\text { (underlining for emphasis added by authors) }\end{array}$ & Nogelmeier (2006) \\
\hline
\end{tabular}

Another site, Lae o Ka 'īlio, is located in the Hā'ena community on the rural north shore of Kaua'i island. Andrade (2008) writes that Lae o Ka 'Îlio translates to 'the headland of the $\operatorname{dog}_{1}$ ' and 'refers to the endangered Hawaiian monk seal known to Hawaiians as 'illio hele i ka uaua (dog running in the rough seas). Residents saw seals there even in the days before the federally established laws now protecting them caused a dramatic increase in their numbers in the main Hawaiian islands' (Andrade 2008). Finally, the modern name Holoikauaua has been given to Pearl and Hermes Atoll in the NWHI. Although the exact origin of the name is unclear, it is stated that the name 'celebrates the Hawaiian monk seals that haul out and rest' at the atoll (USFWS 2008).

There are numerous additional sites throughout the archipelago that may warrant more research, and many of these sites have references to dogs that have ocean connections or descriptions befitting monk seals (Table 2). In the mo'olelo about the god Hi'iakaikapoliopele (Hi'iaka), whose travels through the archipelago are recorded in a lengthy and detailed chant, Hi'iaka describes an area on the island of O'ahu (Ka'o'‘io Point) that is the residence of the 'īlio hā of Kāne, which has 'the body of a massive dog, and the largest expanse of his fur is on his head and neck...' (Nogelmeier 2006) (see the supplement, Section 2). Though it is unknown if this description explicitly refers to monk seals, the description of the 'îlio hā as 'huge, heavy, plump, and fleshy' and as an 'oversized' dog is reminiscent of the physical appearance of monk seals. Unlike the previous mo'olelo, in this story the seal-like animal is associated with the Hawaiian god Kane, who is traditionally associated with dogs. Another site, $\mathrm{Pu}$ 'uanahulu, was 'perhaps named for a supernat- 
ural dog of that name' (Pūkui et al. 1974). The Hawai'i Department of Land and Natural Resources has linked 'Īlio Point, or Kalaeokailio, to an ancient legend of a red dog, rather than a monk seal (DLNR 2009, citing Ne \& Cronin 1992), but monk seals are common to the area (Duvall II 2009). Lae o Ka 'Īlio Point on the northwest tip of Moloka'i, also known as 'İlio Point, bears similarity in name to other points and headlands in Kaua'i, Hawai'i and Maui (Fig. 1, Table 2). Finally, a heiau (ritual site) in the Wai'anae district of O'ahu island, named Kū'ilioloa ('The long dog form of $K \bar{u}^{\prime}$ ), has an associated mo' olelo that references a dog that would bark at the ocean when enemies were approaching. Respondents that identified this site said that although the name has 'illio (dog) in it, it does not necessarily mean it was named after the monk seal.

\section{Interviews in Native Hawaiian communities}

We interviewed a representative cross-section of individuals with different knowledge sets, resource use patterns, perspectives and expertise to uncover cultural information about the Hawaiian monk seal. We also reviewed existing interviews that focused on monk seals, marine environments and similar topics for context. All interviewees indicated that monk seals were relatively new to ocean users in the MHI, with the first personal observations dating to the 1940s and most respondents not indicating experiences with the monk seal until the 1960s. These observations were consistent with previously published ethnographic research among local fishermen and community elders (kūpuna) in the Hawaiian Islands, suggesting perceived rarity among tenured ocean users until the past few decades (Maly \& Maly 2003a,b,c,d, 2004). Many respondents noted that their encounters with monk seals have increased in the past few decades, and these perceptions were similar to those expressed by some community members at public meetings about the monk seal (ERM-West Inc. 2011). A separate survey effort indicated that $>80 \%$ of respondents had personally encountered monk seals in the MHI, but their knowledge of the species was relatively low (SRGII 2011). Respondents' personal experiences are similar to ecological surveys and analyses showing increases in the MHI monk seal population over the past few decades (Baker \& Johanos 2004, Baker et al. 2011).

Respondents exhibited a plurality of views regarding the monk seal, ranging from hostility or ambivalence to strong feelings of conservation and steward- ship based on familial associations with the species. This suggests lack of a consensus in the Native Hawaiian community regarding the monk seal and heterogeneity in perceptions and sociocultural values associated with the species.

Among interviewees that expressed positive views about the monk seal, a small subset indicated a strong sociocultural association with the monk seal. Some interviewees described families on Hawai'i and O'ahu Islands that consider the species to be 'aumakua, the 'family or personal gods, deified ancestors who might assume the shape of...[various animals]' (Pūkui \& Elbert 1986). 'Aumakua are traditionally protected by their associated families, and various cultural protocols are followed to steward the relationships between the family and their 'aumakua. Notably, the monk seal is not named as a common 'aumakua (Pūkui \& Elbert 1986), but this does not necessarily mean that the families have recently adopted this cultural association. 'Aumakua can be associated with families for many generations, reaching far back into history, or can be recent additions based on events that carry special cultural meaning and significance. Additionally, some communities have conducted spiritual ceremonies for monk seals during which the monk seal is recognized as part of the 'ohana, or family. Respondents have said that the details of such activities are deliberately kept hūnā, or secret.

Some respondents shared mo'olelo about monk seals that indicated a mythological association for the species. In one account from the island of Moloka' $i$, a kupuna (community elder) told of a monk seal that washed up without a head in 1947. The kupuna indicated it was the work of Kauhuhu, the famed shark god of the area who patrolled the waters from Moananui to Pelekunu. Another mo'olelo from Hawai'i Island tells of a pair of lovers that suffered the wrath of the jealous shark god Kua. After his affections were spurned, he curses the woman, turning her into a monk seal and her male companion into a butterfly so both could not be together. The pair were later reunited in their human forms by the god Kū (see the supplement, Section 4). These mo'olelo indicate a historical cultural association with the monk seal, but appear to be limited to a few places where familial traditions have preserved the stories.

For some kūpuna, the specific origins of the animal and its significance in Hawaiian culture are irrelevant, as according to these respondents, the traditional Hawaiian sense of stewardship extends to all species and the environment. One respondent, 
for example, expressed, 'whether they are hānai' [adopted] or hānau' [born of, as in a son or daughter], monk seals are part of the ocean and we, humans, have an obligation to protect them.' This perspective has also been shared by other community elders interviewed about the monk seal (videos by T. K. Watson at www.oha.org.hla/HLA159/ and R. Seldon \& J. B. Lucas at www.youtube.com/watch?v= jJsuqUAU_to). These views indicate an evolving sociocultural significance ascribed to the species in the modern context, drawing on traditional conceptions of human-environmental relationships.

While some Native Hawaiian community members hold positive views about the monk seal, many others view the monk seal negatively and do not ascribe any cultural significance to the species historically or in modern times. Among these respondents, the seal is primarily viewed as endemic to the NWHI and not to the MHI. Some respondents view the seal as an invasive species in the MHI and believe the species should remain in the NWHI only. Respondents commonly cite the lack of Hawaiian cultural references to the seal in traditional chants, hula [dance] and other knowledge forms. Other respondents pointed to the lack of evidence that the monk seal was ever used for food, tools, weapons, fabrics, medicine, or combustible material. One respondent emphasized that 'everything in Hawai'i had a common use... since there was no [use], then it must not be native.' Other respondents pointed to the lack of monk seal bones ('iwi) found in archeological excavations. Respondents on Maui were not aware of any place names, sacred sites (wahi pani), or fishing shrines (ko'a) named after the monk seal. They also mentioned that kūpuna (elders), never mentioned the monk seal, and that they did not know of any families that regarded the monk seal as their 'aumakua (spiritual family guardian).

Monk seals are viewed by some respondents as direct competitors to fishers and their families which preferentially take fish specifically targeted by fishers. Many respondents believe that when negative fisheries interactions occur, they inhibit the ability of fishers to provide food for the household. Other fishers cite the aggressive behavior of monk seals as a major problem. These interactions are viewed by some respondents as impacting cultural fishing practices, and are further compounded by existing regulations that restrict fishing (HDAR 2011) and the depleted condition of fisheries resources (Friedlander \& DeMartini 2002, Friedlander 2004). Among these respondents, the view that the monk seal is not endemic is exacerbated by prohibitions against inter- acting with the seal. Respondents believe that modern cultural knowledge cannot be generated because the monk seal 'cannot be touched and used for anything.' Restrictions on use have precluded indigenous communities from perpetuating cultural traditions for other protected species such as sea turtles (Kinan \& Dalzell 2005, Rudrud 2010).

In a few places in the archipelago, monk seals are regarded as a natural part of the ecosystem, and human-monk seal conflicts appear to be minimal. These areas tend to be rural and fairly isolated communities that are characterized by a higher degree of self-sufficiency, and where familial traditions and local decision-making processes are preserved. On Ni'ihau Island, for example, monk seals became established nearly 3 decades ago. Community members discussed the social impacts associated with monk seal colonization (e.g. increased presence of sharks), and ultimately decided to act as stewards of the species (K. Robinson, letter to P. Dalzell, Western Pacific Regional Fishery Management Council, 8 July 2008). As a result, a thriving sub-population has become established, and residents have developed a stewardship ethic towards the species. A similar situation exists in the isolated Kalaupapa community on Moloka'i Island, where another sub-population is thriving in the $\mathrm{MHI}$, and where community residents largely leave seals alone. In these communities, fishers and ocean users will move away from areas with seals in order to minimize interactions.

\section{DISCUSSION}

Our research suggests that the Hawaiian monk seal Monachus schauinslandi was likely extirpated in the MHI soon after voyaging Polynesians settled in the archipelago ( AD 1250). Though several other competing hypotheses remain (Watson et al. 2011), based on our review of the available information, the most likely explanation is that seal populations were probably rapidly diminished by human hunters and harassment by their commensals soon after initial arrival. This theory has been advanced before in several forms (e.g. Kenyon 1980), but to our knowledge has not been substantiated with a comprehensive review of archival sources. Monk seals were probably rare, but not absent, in the MHI through the many centuries during which pre-contact Native Hawaiian societies developed in the archipelago. In the post-sealing era of the early 20th century, various human perturbations in the NWHI kept populations relatively low until the species was protected under 
the Endangered Species Act in the 1970s (Kenyon 1972, 1980). Starting in approximately the mid1990s, seal populations have begun re-populating the MHI (Baker \& Johanos 2004), leading to increased conflicts with ocean users. Below, we discuss the heterogenous nature of cultural information about the monk seal, the relevance of historical baselines to species recovery, and the application of sociocultural information to conservation planning.

\section{Heterogeneity in traditional ecological knowledge and cultural endemism}

Our research on the sociocultural significance of the species suggests that the monk seal is not uniformly known to Native Hawaiian communities. There is little evidence that monk seals played a significant role in traditional Hawaiian culture in preWestern contact (prior to AD 1778) or historical times. Cultural references and traditional ecological knowledge for the monk seal appear to be sequestered in specific knowledge systems ascribed to either a specific place, familial association, or oral tradition. References to the species are also inconsistent in Native Hawaiian cultural knowledge forms. For example, some references associate monk seals with the god Lono, while other mo'olelo point to an association with a different god (e.g. Kū) or to a local demi-god or place name. Cultural knowledge thus appears to be heterogenous in distribution among Native Hawaiian knowledge domains.

We advance the notion of 'cultural endemism' to explain how place influences the development and maintenance of sociocultural knowledge domains. We define cultural endemism as the set of sociocultural values, norms, practices and traditions that develop in a place-specific context for a discrete - or set of linked - natural or anthropogenic phenomena. Variation in traditional ecological knowledge due to place-specific factors (social and ecological) may result in heterogeneity in knowledge systems and related practices and traditions. The development of cultural endemism for a species appears to be a result of reciprocal interactions, whereby the most vulnerable taxa may be reduced faster than the development of a cultural profile, and high-value resources that are more resistant to initial impacts become more fully integrated into traditions, values and practices as a mechanism for perpetuation of both the resource and its cultural dimensions (Kittinger et al. 2011).

Our research on the monk seal suggests that, although the monk seal is biologically endemic, the species is not uniformly culturally endemic in Hawaiian communities. This heterogeneity can be explained by historical rarity, indigenous Hawaiian approaches to categorization of phenomena, and the dispersed mode of traditional knowledge production in Hawai'i. Historical ecological rarity likely precluded the uniform development of a cultural profile for monk seals and further integration into Native Hawaiian cultural practices and traditions. In some areas, monk seals have been incorporated into cultural lore and memory, but these cultural references are not widely known to the broader Native Hawaiian community. According to Charlot (2005), observation formed the basis for indigenous Hawaiian classification systems and hierarchical organization of phenomena. Phenomena that were common and reliably observed could be, and were, used with confidence, but apparently Hawaiians showed less interest in borderline cases, such as that of the monk seal, that are hard to categorize or cross categories or divisions (Charlot 2005, p. 232).

Diversity and lack of consistency in cultural sources and contexts also likely contributed to the dispersed manner in which knowledge is generated, maintained and built upon in Native Hawaiian communities. Traditionally, cultural knowledge systems accumulate at the local level through kinship networks and familial ties based in traditionally defined communities, defined as mountain-to-sea systems based in single watersheds (ahupua'a). These knowledge systems consist of a rich pool of collective memories that encompass an inherited culture in Native Hawaiian communities (Kikiloi 2010). Cultural knowledge may have aggregated at higher levels through a myriad of mechanisms that dispersed and shared cultural traditions among communities and at higher levels of social organization. Because knowledge was preserved in non-written traditions (e.g. oral, dance), the production of knowledge resulted in a heterogenous, poly-rhetoric knowledge landscape, with variation due to social and environmental geography (Nogelmeier 2010). Local development of situated knowledge can help explain spatial variation in cultural practices and traditions, and may be partly responsible for the different names, cultural associations and significance ascribed to monk seals.

Though historical associations exhibit heterogenous patterns in cultural endemism, monk seals are currently developing a more substantive cultural profile in contemporary Hawaiian communities, evidencing evolving social norms and values for the species. This is due in part to the increased occurrence of monk seals in the MHI. Perceptions of the 
monk seal appear to be dichotomous, with one epistemic community that views monk seals as alien and another set of communities that have retained, enhanced, or engendered a Native Hawaiian cultural association with monk seals. Community members adverse to the monk seal associate little or no historical cultural references to monk seals, primarily include fishers and their families, and associate the monk seal with increased restrictions on cultural activities and practices, particularly fishing.

Communities that co-exist peaceably with the monk seal tend to be rural, somewhat isolated, and less integrated in the socioeconomic systems that support urban communities in the archipelago. McGregor has termed such communities as cultural kippuka, where traditional livelihoods, cultural practices and ways of life have persisted relatively untouched, and which provide the seeds by which Native Hawaiian culture is regenerated, relearned and revitalized in the setting of modern Hawai'i (McGregor 2007). Kikiloi (2010) has posited that this process of re-learning and developing new knowledge is a fundamental aspect of sustaining a Hawaiian cultural identity and spiritual connections to land and place.

\section{Historical rarity, shifting baselines, and species recovery}

Shifting baselines refers to the process by which each generation calibrates their perceptions of environmental conditions via their first association with the marine environment (Pauly 1995, Jackson et al. 2011). Shifting baselines can provide a substantive challenge for conservation programs if people's personal experiences are incongruent with longer term ecological baselines for species and habitats that span one or more human generations (Papworth et al. 2009). For example, Waldman (2010) has described a process of 'eco-social anomie,' where, as species disappear, they lose both relevance to a society and the constituency to champion their revival, further hastening their decline. Waldman cites the examples of wild Atlantic salmon, shad and alewives, which once provided vital sources of food and employment for communities but are no longer part of people's everyday experiences.

For species recovery, the process appears to be the reverse. Species recovery for long-lived and slow-growing animals, such as marine mammals or sea turtles, can take decades and, as species repopulate historical ranges, they can be viewed as new arrivals by residents whose personal baselines are shorter than species' long-term trajectories of decline and recovery (often on the scales of decades to centuries). The recolonization of the MHI by monk seals over the past few decades thus describes a process of reverse eco-social anomie, where the species' increased presence is resulting in evolving social norms and values for the species, and is enlivening human-wildlife conflicts with some ocean users.

Similar trends have been noted for recovering species both currently and in the recent past. For example, fisheries conflicts occurred with sea otters after they re-populated the central and northern coasts of California in the mid-20th century after near-extinction due to hunting in the 18th and 19th centuries. As sea otters moved north along the central California coast, their presence resulted in major declines in the abundances and accessibility of commercially valuable shellfish species, and fishing communities viewed otters as threats to their livelihoods (Estes \& VanBlaricom 1986, Watson 2000, Palumbi \& Sotka 2010). Like the monk seal, the sea otter conflicted primarily with fishers, and significant disparities existed among stakeholder groups in their values and perceptions of the species (Cicin-Sain et al. 1982, Palumbi \& Sotka 2010). Similar situations are occurring currently with pinnipeds in New Zealand (Childerhouse \& Gales 1998) and mammals in the Arctic (Lovecraft \& Meek 2011, Varjopuro 2011).

\section{Applying sociocultural dimensions to species conservation planning}

Though species recovery can be viewed as conservation success, the repopulation of species to their historical ranges can also fuel conflicts with ocean user communities that do not associate the species with their area and view it as a new arrival. Such human-wildlife conflicts are likely to be exacerbated in situations where wildlife threatens human activities or livelihoods (Treves et al. 2009). From a social perspective, understanding how humans interacted with protected species in the past and in contemporary communities can help inform conservation planning and management actions (Tarrant et al. 1997, Cordell et al. 1999, Watson et al. 2011). The management of endangered species, for example, depends, in part, on the ability of managers and their conservation programs to engage productively with communities and stakeholders in stewardship and recovery efforts. 
Participatory approaches to resource management have increasingly gained attention for their potential to engage resource users and communities in the development, implementation and evaluation of management actions or strategies. Participatory management has been described as involving stakeholders in the process of decision-making, which can promote common knowledge among communities, resource users and managers and result in better success and efficacy for resource management plans (Kapoor 2001, Negi 2001, Chuenpagdee et al. 2004, Dale \& Armitage 2011). Stakeholder participation in human-wildlife conflict analyses and the design of long-term conflict transformation strategies can facilitate collaborative learning processes among individuals, institutions and sectors working on, or affected by, conflicts in conservation (e.g. Muro \& Jeffrey 2008; www.humanwildlifeconflict.org). For wildlife and endangered species, participatory planning can also increase understanding about the root causes for conflict and the possible focal points for successful interventions (Treves 2008, Treves et al. 2009). Such approaches have also been shown to increase local capacity and build stewardship among communities for more effective conservation (Jackson \& Wangchuk 2001, Treves et al. 2009, Dale \& Armitage 2011).

Like other species that have begun repopulating previous ranges, the Hawaiian monk seal is presenting new challenges to conservation programs as new values and evolving social norms for the species develop. As monk seal numbers have increased in the MHI, community concerns have emerged about the effect this increased population will have on cultural resources and subsistence activities, including fishing. If current trends continue, the sub-population of monk seals in the MHI is expected to exceed that of the NWHI by 2024 to 2035 (Baker et al. 2011). From a species conservation perspective, the increased habitat and carrying capacity, particularly in the availability of sandy beaches (Ragen 2002), and the establishment of small but growing rookeries in the MHI provide an important hedge against the possibilities of major perturbations in the future (e.g. disease outbreaks, oil spills, climate change) (Baker et al. 2006). Among community members that have adverse views toward the monk seal, however, this increase may be viewed as a cause for concern and may result in increased human-monk seal conflicts if actions are not taken to successfully reduce user conflicts.

Participatory approaches to planning for species recovery may help to diffuse conflicts by enabling stakeholders to collaborate in designing management strategies and in evaluating specific management actions in a place-based manner. For example, heterogeneity in values and perceptions among Hawaiian communities could help inform or proactively evaluate the current practice of translocating seals from the NWHI to the MHI. This practice is viewed negatively by many fishers, both because of the perceived threat of additional monk seals as competitors for fisheries resources, but also because it is seen as an intrusion of federal government programs on local customs and practices. Translocations, and other management actions that may increase user conflicts, ideally should be evaluated within a place-based context (e.g. translocation could only target places with existing positive relationships with seals) to minimize conflicts with specific user groups. Such management actions may be necessary in order to ensure persistence of endangered species under existing and emerging threats, but potential conflicts should ideally be evaluated to reduce short-term extinction risk as well as longer term social acceptance of monk seals as part of Hawaiian seascapes.

Finally, resource management and conservation planning actions that are viewed within the broader context of increased restrictions on local communities can exacerbate stakeholders' views that they are alienated from decision-making processes. This is particularly relevant in indigenous communities, where top-down approaches to conservation plans may be viewed as eroding customary resource rights that have a history of state-mediated decline (Bess 2001, Kishigami \& Savelle 2005, Lowe \& Carothers 2008). For these reasons, management and planning processes for the monk seal could benefit from increased sensitivity to the fact that species conservation issues are embedded in larger scale dynamics of indigenous involvement in resource governance in the Hawaiian Islands. Management actions can provide an opportunity for cross-cultural engagement and co-learning processes, or opportunity for further conflict and balkanization between various stakeholder groups, which depend substantively on the planning process approach and engagement strategy employed. The future development of a cultural profile for monk seals will depend largely upon how Hawaiian communities and other stakeholders will interact with the planning and decision-making process for the species. Involvement of user groups and stakeholders and their traditional ecological knowledge in participatory decision-making processes may hold promise for reducing wildlife conflicts and 
improving collaborative environmental stewardship generally.

\section{CONCLUSIONS}

In conclusion, historical ecological data can shed light on environmental changes that transcend human generations, but our research also highlights the importance of understanding past social relationships with species. Such information can be valuable for understanding human-environmental dynamics, the evolving social context relevant to current conservation planning, and future prospects for different management actions. For the monk seal, both historical and contemporary sociocultural associations appear heterogenous, but are evolving as the monk seal increases in abundance in the MHI. Monk seals and other species that are repopulating previous historical ranges will spark the development of new cultural associations with evolving social norms and values among different stakeholders and communities. A key consideration is how recovering species will be integrated into the cultures and social traditions of coastal communities. This will depend in part on the cultural exchange between species and oceanuser groups, which is mediated by planning processes and species recovery policy. Participatory approaches to managing species that seek to construct collaborative conservation plans with resource users and stakeholders may hold promise for reducing conflicts and ensuring more effective conservation success. For monk seals and other endangered species that involve human-wildlife conflict, the future of recovery and conservation programs will depend, in part, on the productive engagement of stakeholder groups, which can be aided by sociocultural assessments of historical and contemporary values, perceptions and practices associated with species. Social science research can provide important baseline information that can be used to assess changes in these social metrics through time, and such data are potentially valuable for managers and programs seeking to engage more effectively with communities in species recovery and conservation efforts.

Acknowledgements. We thank first and foremost the Native Hawaiian cultural practitioners and community members who have shared their mana'o with us. The knowledge, perceptions and information about monk seals and Native Hawaiian culture described herein belong to these respondents and their communities. We also thank Bill Gilmartin, Bud Antonelis, Puakea Nogelmeier, Loren E. McClenachan,
Bob Rechtman and Craig Severance who have shared their knowledge about monk seals and Hawaiian communities with us. This research was supported by competitive grants from the Protected Species Division, Pacific Islands Regional Office, National Marine Fisheries Service, and we thank Jeffrey Walters for their support. Any errors or omissions belong to the authors alone.

\section{LITERATURE CITED}

Allen MS (2007) Three millennia of human and sea turtle interactions in remote Oceania. Coral Reefs 26:959-970

Alu Like, Hale Kuamo`o, Bernice P. Bishop Museum (2006). Ho'olaupa'i, Hawaiian Nūpepa collection. Online database available at www.nupepa.org

Andrade C (2008) Hā'ena: through the eyes of the ancestors. University of Hawai'i Press, Honolulu, HI

Andrews L (1865) A dictionary of the Hawaiian language. Henry M. Whitney, Honolulu, HI

Anonymous (1857) The French man-o-war eurydice... 'Elepani o ke kai, Ka Hae Hawaii, Book 7, p 25, 14 May 1857, Honolulu, HI

Anonymous (2010) Feds investigating death of monk seal pup found off Niihau. Hawaii News Now, July 28, 2010. Available at www.hawaiinewsnow.com/story/12885862/ feds-investigating-death-of-monk-seal-pup-found-offniihau

Antonelis GA, Baker JD, Johanos TC, Braun RC, Harting AL (2006) Hawaiian monk seal (Monachus schauinslandi): status and conservation issues. Atoll Res Bull 543:75-101

Aswani S, Hamilton RJ (2004) Integrating indigenous ecological knowledge and customary sea tenure with marine and social science for conservation of bumphead parrotfish (Bolbometopon muricatum) in the Roviana Lagoon, Solomon Islands. Environ Conserv 31:69-83

Athens J (2009) Rattus exulans and the catastrophic disappearance of Hawai'i's native lowland forest. Biol Invasions 11:1489-1501

Baker JD, Johanos TC (2004) Abundance of the Hawaiian monk seal in the main Hawaiian Islands. Biol Conserv 116:103-110

> Baker JD, Littnan CL, Johnston DW (2006) Potential effects of sea level rise on the terrestrial habitats of endangered and endemic megafauna in the northwestern Hawaiian Islands. Endang Species Res 2:21-30

Baker JD, Harting AL, Wurth TA, Johanos TC (2011) Dramatic shifts in Hawaiian monk seal distribution predicted from divergent regional trends. Mar Mamm Sci 27:78-93

Balazs GH, Whittow GC (1979) Revised bibliography of the Hawaiian monk seal: Monachus schauinslandi Matschie, 1905. Sea Grant Miscellaneous Report UNIHI-SEAGRANT-MR-79-03, Sea Grant College Program, University of Hawaii, Honolulu, HI

Barbour RS (2001) Checklists for improving rigour in qualitative research: a case of the tail wagging the dog? BMJ 322:1115-1117

Bath AJ (1998) The role of human dimensions in wildlife resource research in wildlife management. Ursus 10: 349-355

- Baxter J, Eyles J (1997) Evaluating qualitative research in social geography: establishing 'rigour' in interview analysis. Trans Inst Br Geogr 22:505-525

Beckley EM (1883) Hawaiian fisheries and methods of fishing with an account of the fishing implements used by 
the natives of the Hawaiian Islands. Advertiser Steam Print, Honolulu, HI

Beckwith MW (1951) The kumulipo: a Hawaiian creation chant. University of Chicago Press, Chicago, IL

Beechert ED (1991) Honolulu: crossroads of the Pacific. University of South Carolina Press, Columbia, SC

Bentrupperbaumer JM, Day TJ, Reser JP (2006) Uses, meanings, and understandings of values in the environmental and protected area arena: a consideration of world heritage values. Soc Nat Resour 19:723-741

Bernard HR (2006) Research methods in anthropology: qualitative and quantitative approaches. AltaMira Press, Oxford

Bess R (2001) New Zealand's indigenous people and their claims to fisheries resources. Mar Policy 25:23-32

Burney DA, James HF, Burney LP, Olson SL and others (2001) Fossil evidence for a diverse biota from Kaua' $i$ and its transformation since human arrival. Ecol Monogr 71: 615-641

Charlot J (2005) Classical Hawaiian education: generations of Hawaiian culture. The Pacific Institute, Brigham Young University, Hawai'i, Lā'ie, HI

Childerhouse S, Gales N (1998) Historical and modern distribution and abundance of the New Zealand sea lion Phocarctos hookeri. NZ J Zool 25:1-16

Chuenpagdee R, Fraga J, Euan-Avila JI (2004) Progressing toward comanagement through participatory research. Soc Nat Resour 17:147-161

Cicin-Sain B, Grifman PM, Richards JB (eds) (1982) Social science perspectives on managing conflicts between marine mammals and fisheries. Marine Policy Program, University of California at Santa Barbara, Santa Barbara, and University of California Cooperative Extension, San Luis Obispo, CA

Cinner JE, McClanahan TR, Daw TM, Graham NAJ, Maina J, Wilson SK, Hughes TP (2009) Linking social and ecological systems to sustain coral reef fisheries. Curr Biol 19:206-212

Clark TW, Reading RP, Clark AL (1994) Endangered species recovery: finding the lessons, improving the process. Island Press, Washington, DC

Cobb JN (1905) The commercial fisheries of the Hawaiian Islands in 1903. Appendix to the report of the Commissioner of Fisheries to the Secretary of Commerce and Labor for the year ending June 30, 1904. Department of Commerce and Labor, US Bureau of Fisheries, Government Printing Office, Washington, DC, p 433-512

Cordell HK, Hoover AP, Super GR, Manning CH (1999) Adding human dimensions to ecosystem-based management of natural resources. In: Cordell HK, Bergstrom JC (eds) Integrating social sciences with ecosystem management: human dimensions in assessment, policy, and management. Sagamore, Champaign, IL, p 1-12

Dale A, Armitage D (2011) Marine mammal co-management in Canada's arctic: knowledge co-production for learning and adaptive capacity. Mar Policy 35:440-449

DLNR (Department of Land and Natural Resources) (2009) Draft report for the 'İlio Point Natural Area Reserve, State of Hawai‘i. DLNR, Honolulu, HI. Available at http://hawaii.gov/dlnr/dofaw/nars/reserves/molokai/ilio -point

Duvall FP II (2009) Management document: 'Īlio and Koa special areas: 'Īlio Point Moloka'i, State of Hawai'i. Department of Land and Natural Resources, Honolulu, HI.
Available at http://hawaii.gov/dlnr/dofaw/nars/reserves/ molokai/ilio-point

Elbert S (1954) The Hawaiian dictionaries, past and future. Sixty-second Annual Report of the Hawaiian Historical Society, Honolulu, HI, p 5-18

ERM-West Inc (2011) Scoping summary report: Hawaiian monk seal recovery actions. Programmatic EIS, National Marine Fisheries Service, Pacific Islands Regional Office, Anchorage, AK. Available at www.nmfs.noaa.gov/pr/ pdfs/permits/eis/01-31-2011_final_scoping_report.pdf

Estes JA, VanBlaricom GR (1986) Sea otters and shellfisheries. In: Beddington JR, Beverton RJH, Levigne DM (eds) Marine mammals and fisheries. George Allen \& Unwin, London, p 187-235

Fornander A (1916-1920) Fornander collection of Hawaiian antiquities and folk-lore. In: Memoirs of the Bernice P. Bishop Museum, Vols 4-6. Bernice P. Bishop Museum Press, Honolulu, HI

Friedlander AM (ed) (2004) Status of Hawai'i's coastal fisheries in the new millennium: Proc 2001 Fish Symp. Hawai'i Chapter, The American Fisheries Society, Honolulu, HI

Friedlander AM, DeMartini EE (2002) Contrasts in density, size, and biomass of reef fishes between the northwestern and the main Hawaiian islands: the effects of fishing down apex predators. Mar Ecol Prog Ser 230:253-264

Gilmartin WG (2002) Responses of Hawaiian seals to human disturbance and handling. In: Background documents: workshop on the management of Hawaiian monk seals on beaches in the main Hawaiian Islands. Marine Mammal Commission, National Marine Fisheries Service, Hawai'i Division of Aquatic Resources, Koloa, Kaua ‘i, HI, p 29-31

Glaser B, Strauss A (1967) The discovery of grounded theory: strategies for qualitative research. Aldine, New York, NY

Handy ESC, Pūkui MK (1972) The Polynesian family system in Ka‘u Hawai‘i. C.E. Tuttle Company, Rutland, VT

HDAR (Hawai‘i Division of Aquatic Resources) (2011) Fishing regulations. HDAR, Honolulu, HI. Available at http:// hawaii.gov/dlnr/dar/regulations.html (accessed on 4 Jan 2012)

Hiruki LM, Ragen TJ (1992) A compilation of historical monk seal, Monachus schauinslandi, counts. US Department of Commerce NOAA Tech Memo NMFS, NOAATM-NMFS-SWFSC-172

' $\bar{I} ' \overline{1}$ JP (1993) Fragments of Hawaiian history. Translated from Hawaiian to English by Mary Kawena Pūkui (edited by Dorothy B. Barrère). Bishop Museum Press, Honolulu, $\mathrm{HI}$

IUCN (International Union for the Conservation of Nature) (2011) IUCN Red List of threatened species, Version 2011.1. Available at www.iucnredlist.org (accessed on 14 Sept 2011)

Jackson R, Wangchuk R (2001) Linking snow leopard conservation and people-wildlife conflict resolution: grassroots measures to protect the endangered snow leopard from herder retribution. Endang Species Update 18: $138-141$

Jackson JBC, Alexander K, Sala E (eds) (2011) Shifting baselines: the past and future of ocean fisheries. Island Press, Washington, DC

Jacobson SK, Duff MD (1998) Training idiot savants: the lack of human dimensions in conservation biology. Conserv Biol 12:263-267 
Jokiel PL, Rodgers KS, Walsh WJ, Polhemus DA, Wilhelm TA (2011) Marine resource management in the Hawaiian archipelago: the traditional Hawaiian system in relation to the western approach. J Mar Biol 151682. Available at www.hindawi.com/journals/jmb/ 2011/151682/

Kamakau SM (1992) The people of old. Translated from the newspaper Ke Au 'Oko'a by Mary Kawena Pūkui (edited by Dorothy B. Barrère). Spec Publ No. 51, Bernice P. Bishop Museum, Honolulu, HI

Kaneshiro KY, Chinn P, Duin KN, Hood AP, Maly K, Wilcox BA (2005) Hawai'i's mountain-to-sea ecosystems: social-ecological microcosms for sustainability science and practice. EcoHealth 2:349-360

Kapoor I (2001) Towards participatory environmental management? J Environ Manag 63:269-279

Kellert SR (1985) Social and perceptual factors in endangered species management. J Wildl Manag 49: 528-536

Kellert SR (1986) Social and perceptual factors in the preservation of animal species. In: Norton B (ed) The preservation of species. Princeton University Press, Princeton, NJ, p 50-73

Kenyon KW (1972) Man versus the monk seal. J Mammal 53: 687-696

Kenyon KW (1980) No man is benign: the endangered monk seal. Oceans 13:48-54

Kenyon KW, Rice DW (1959) Life history of the Hawaiian monk seal. Pac Sci 13:215-252

Kikiloi K (2010) Rebirth of an archipelago: sustaining a Hawaiian cultural identity for people and homeland. Hūlili: Multidis Res on Hawaiian Well-Being 6:73-114 Available at www.ksbe.edu/spi/Hulili/Hulili_vol6/5_ Rebirth_of_an_Archipelago.pdf

Kinan I, Dalzell P (2005) Sea turtles as a flagship species: different perspectives create conflicts in the Pacific Islands. Maritime Studies 3:195-212. Available at www. marecentre.nl/mast/ContentsMarineTurtlesasFlagships. html

Kirch PV (1985) Feathered gods and fishhooks: an introduction to Hawaiian archaeology and prehistory. University of Hawai'i Press, Honolulu, HI

Kishigami N, Savelle JM (eds) (2005) Indigenous use and management of marine resources. Senri Ethnological Studies 67, National Museum of Ethnology (MINPAKU), Osaka

Kittinger JN, Pandolfi JM, Blodgett JH, Hunt TL and others (2011) Historical reconstruction reveals recovery in Hawaiian coral reefs. PLoS ONE 6:e25460

Kōmike Hua ‘ōlelo (2003) Māmaka Kaiao: a modern Hawaiian vocabulary: a compilation of Hawaiian words that have been created, collected, and approved by the Hawaiian lexicon committee from 1987 through 2000. University of Hawai'i at Hilo, Hale Kuamo‘o, University of Hawai'i Press, Honolulu, HI

Kuykendall RS (1929) Some early commercial adventures of Hawaii. In: The 37th annual report of the Hawaiian historical society. Hawaiian historical society, Honolulu, HI, p 15-33

Kuykendall RS (1938) The Hawaiian kingdom, Vol. I: 1778-1854 foundation and transformation. University of Hawaii Press, Honolulu, HI

Kuykendall RS (1957) The Hawaiian kingdom, Vol. II: 1854-1874, twenty critical years. University of Hawaii Press, Honolulu, HI
Kvale S (1996) Interviews: an introduction to qualitative research interviewing. Sage, London

Levine M (2009) Monk seal shooter pleads guilty. The Garden Isle, Lihue, September 26, 2009. Available at http: //thegardenisland.com/news/local/article_3222caae-d35a5a0b-8850-7a901768e192.html

Lovecraft AL, Meek CL (2011) The human dimensions of marine mammal management in a time of rapid change: comparing policies in Canada, Finland and the United States. Mar Policy 35:427-429

Lowe M, Carothers C (eds) (2008) Enclosing the fisheries: people, places, and power. American Fisheries Society, Bethesda, MD

Maly K (2001) Mālama pono i ka 'āina — an overview of the Hawaiian cultural landscape. Kumu Pono Associates LLC, Lana'i City, HI

Maly K, Maly O (2003a) 'Hana ka lima, 'ai ka waha': a collection of historical accounts and oral history interviews with kama'aina residents and fisher-people of lands in the Halele'a-Napali region on the island of Kaua'i. Kumu Pono Associates. Prepared for The Nature Conservancy, Honolulu, HI

Maly K, Maly O (2003b) He wahi mo‘olelo no na lawai‘a ma kapalilua, Kona hema, Hawai'i: a collection of historical accounts and oral history interviews with elder kama'aina fisher-people from the Kapalilua region of south Kona, island of Hawai'i. Kumu Pono Associates. Prepared for The Nature Conservancy, Honolulu, HI

Maly K, Maly O (2003c) Vol 1: Ka hana lawai‘a a me na ko‘a o na kai 'ewalu: a history of fishing practices and marine fisheries of the Hawaiian islands, compiled from native Hawaiian traditions, historical accounts, government communications, kama'aina testimony and ethnography. Kumu Pono Associates. Prepared for The Nature Conservancy, Honolulu, HI

Maly K, Maly O (2003d) Vol 2: Oral history interviews. Ka hana lawai'a a me na ko'a o na kai 'ewalu: a history of fishing practices and marine fisheries of the Hawaiian islands, compiled from oral history interviews with kupuna and kama'aina. Kumu Pono Associates. Prepared for The Nature Conservancy, Honolulu, HI

Maly K, Maly O (2004) Ka hana lawai‘a a me na ko‘a o na kai 'ewalu: summary of detailed findings from research on the history of fishing practices and marine fisheries of the Hawaiian islands, compiled from native Hawaiian traditions, historical accounts, government communications, kama'aina testimony and ethnography. Kumu Pono Associates. Prepared for The Nature Conservancy, Honolulu, HI

Maxwell J (1997) Designing a qualitative study. In: Bickman L, Rog DJ (eds) Handbook of applied social research methods. Sage Publications, Thousand Oaks, CA, p 69-100

McAvoy A (2012) Hawaii hit by number of endangered seal killings. The Associated Press, 8 January 2012, Honolulu, HI. Available at http://hawaiitribune-herald.com/ sections/news/local-news/new-threat-monk-seals.html

McGregor D (2007) Na Kua‘Āina: living Hawaiian culture. Bishop Museum Press, Honolulu, HI

Muro M, Jeffrey P (2008) A critical review of the theory and application of social learning in participatory natural resource management processes. J Environ Plan Manage 51:325-344

Nasako D (2012) The endangered monk seal: fight for survival. Honolulu Star-Advertiser, 15 January 2012, Honolulu, HI, p A1, A8-10 
Naughton EM (1983) Hawaiians in the fur trade: cultural influence on the northwest coast, 1811-1875. MA thesis, Western Washington University, Bellingham, WA

Ne H, Cronin GL (1992) Tales of Molokai: the voice of Harriet Ne. The Institute for Polynesian Studies and the Polynesian Cultural Center, Brigham Young UniversityHawai'i, Lā'ie, HI

Negi SS (2001) Participatory natural resource management. Indus Publishing, New Delhi

Nerveza TL (2010) Cultural significance of the Hawaiian monk seal. Pacific Internship Programs for Exploring Science (PIPES) report, University of Hawai'si at Hilo, Pacific Aquaculture and Coastal Resources Center, Hilo, HI

NMFS (National Marine Fisheries Service) (2007) Recovery plan for the Hawaiian monk seal (Monachus schauinslandi), 2nd revision. NMFS, Silver Spring, MD. Available at www.nmfs.noaa.gov/pr/pdfs/recovery/hawaiian monkseal.pdf

Nogelmeier MP (2006) Ka mo‘olelo o Hi‘iakaikapoliopele (the epic tale of Hi'iakaikapoliopele) (Nogelmeier MP, translator). Awaiaulu Press, Honolulu, HI

Nogelmeier MP (2010) Mai pa'a i ka leo: historical voice in Hawaiian primary materials, looking forward and listening back. Bishop Museum Press, Honolulu, HI

Office of Hawaiian Affairs (2010) Papakilo database. Office of Hawaiian Affairs. Available at www.papakilodata base.com

Osher W (2011) Moloka‘i monk seal deaths deemed suspicious. MauiNow.com: Maui's news \& information hub. 23 December 2011. Available at http://mauinow.com/2011/ 12/23/moloka \%E2 \% $80 \%$ 98i-monk-seal-deaths-underinvestigation/

Palumbi SR, Sotka C (2010) The death and life of Monterey Bay: a story of revival. Island Press, Washington, DC

Papworth SK, Rist J, Coad L, Milner-Gulland EJ (2009) Evidence for shifting baseline syndrome in conservation. Conservation Letters 2:93-100

Parker HH (ed) (1922) A dictionary of the Hawaiian language (by Lorrin Andrews, revised by Henry $\mathrm{H}$. Parker). Board of Commissioners of Public Archives, Honolulu, HI

Pauly D (1995) Anecdotes and the shifting baseline syndrome of fisheries. Trends Ecol Evol 10:430-430

Penrod J, Preston DB, Cain RE, Starks MT (2003) A discussion of chain referral as a method of sampling hard-toreach populations. J Transcult Nurs 14:100-107

Pūkui MK, Elbert SH (1971) Hawaiian dictionary: Hawaiian-English and English-Hawaiian, 4th edn, University of Hawai'i Press, Honolulu, HI

Pūkui MK, Elbert SH (1986) Hawaiian dictionary: Hawaiian-English and English-Hawaiian (revised and enlarged 6th edn). University of Hawai'i Press, Honolulu, $\mathrm{HI}$

Pūkui MK, Elbert SH, Mo‘okini ET (1974) Place names of Hawai'i. University of Hawai'i Press, Honolulu, HI

Ragen TR (1999) Human activities affecting the population trends of the Hawaiian monk seal. In: Musick JA (ed) Life in the slow lane: ecology and conservation of long-lived marine animals. Proc Symp Conservation of long-lived marine animals. American Fisheries Society Symposium 23, Bethesda, MD, p 183-194

Ragen TJ (2002) The role of the main Hawaiian islands in the recovery of the Hawaiian monk seal. In: Background documents: workshop on the management of Hawaiian monk seals on beaches in the main Hawaiian islands. Marine Mammal Commission, National Marine Fisheries Service, Hawai‘i Division of Aquatic Resources, Koloa, Kaua'i, HI

Ragen TJ, Lavigne DM (1999) The Hawaiian monk seal: biology of an endangered species. In: Twiss Jr JR, Reeves RR (eds) Conservation and management of marine mammals. Smithsonian Institution Press, Washington, DC, p 224-245

Ralston C (1984) Hawaii 1778-1854: some aspects of maka'ainana response to rapid cultural change. J Pac Hist 19:21-40

Romney AK, Weller SC, Batchelder WH (1986) Culture as consensus: a theory of culture and informant accuracy. Am Anthropol 88:313-338

Rosendahl PH (1994) Aboriginal Hawaiian structural remains and settlement patterns in the upland archeological zone at Lapakahi, island of Hawaii. Hawaiian Archaeol 3:14-70

Rudrud R (2010) Forbidden sea turtles: traditional laws pertaining to sea turtle consumption in Polynesia (including the Polynesian outliers). Conserv Soc 8:84-97

Schatzman L (1991) Dimensional analysis: notes on an alternative approach to the grounding of theory on qualitative research. In: Maines DR (ed) Social organization and social process: essays in honor of Anselm Strauss. Aldine, New York, NY, p 303-314

Seaton S (1974) The Hawaiian 'kapu' abolition of 1819. Am Ethnologist 1:193-206

Seidman I (1998) Interviewing as qualitative research: a guide for researchers in education and the social sciences. Teachers College Press, New York, NY

Shackeroff JM, Campbell LM (2007) Traditional ecological knowledge in conservation research: problems and prospects for their constructive engagement. Conserv Soc 5:e343-e360

Shackeroff JM, Campbell LM, Crowder LB (2011) Socialecological guilds: putting people into marine historical ecology. Ecol Soc 16:52 Available at www.ecologyand society.org/vol16/iss51/art52/

SRGII (Sustainable Resources Group Int'l, Inc.) (2011) Public perception and attitudes about the Hawaiian monk seal: survey results report. Report submitted by SRGII to Protected Resources Division, NOAA Fisheries Honolulu, HI

Tarrant MA, Bright AD, Cordell HK (1997) Attitudes toward wildlife species protection: assessing moderating and mediating effects in the value-attitude relationship. Hum Dimens Wildl 2:1-20

Thomas G, James D (2006) Reinventing grounded theory: some questions about theory, ground and discovery. $\mathrm{Br}$ Educ Res J 32:767-795

Titcomb M (1972) Native use of fish in Hawaii. The University Press of Hawaii, Honolulu, HI

Treves A (2008) Beyond recovery: Wisconsin's wolf policy 1980-2008. Hum Dimens Wildl 13:329-338

> Treves A, Wallace R, White S (2009) Participatory planning of interventions to mitigate human-wildlife conflicts. Conserv Biol 23:1577-1587

Ulukau (2003) Ulukau: Hawaiian electronic library, online database. Available at www.wehewehe.org

USFWS (US Fish and Wildlife Service) (2008) Papahānaumokuākea Marine National Monument. Monument Management Plan. USFWS, National Oceanic and Atmospheric Administration, State of Hawai'i, Department of Land and Natural Resources, Honolulu, HI 
Varjopuro R (2011) Co-existence of seals and fisheries? Adaptation of a coastal fishery for recovery of the Baltic grey seal. Mar Policy 35:450-456

Vitousek PM, Ladefoged TN, Kirch PV, Hartshorn AS and others (2004) Soils, agriculture, and society in precontact Hawaii. Science 304:1665-1669

Waldman J (2010) The natural world vanishes: How species cease to matter. Yale Environment 360, 8 April 2010. Available at http://e360.yale.edu/content/feature.msp? $\mathrm{id}=2258$

Watson J (2000) The effects of sea otters (Enhydra lutris) on abalone (Haliotis spp.) populations. In: Campbell A (ed)

Editorial responsibility: Jason Matthiopoulos,

Fife, UK
Workshop on rebuiding abalone stocks in British Columbia. Canadian Special Publication of Fisheries and Aquatic Sciences 130, National Research Council of Canada, Ottawa, p 123-132

Watson TK, Kittinger JN, Walters JS, Schofield TD (2011) Culture, conservation and conflict: assessing the human dimensions of Hawaiian monk seal recovery. Aquat Mamm 37:386-396

Wilmshurst JM, Hunt TL, Lipo CP, Anderson AJ (2011) High-precision radiocarbon dating shows recent and rapid initial human colonization of East Polynesia. Proc Natl Acad Sci USA 108:1815-1820

Submitted: September 15, 2011; Accepted: February 5, 2012 Proofs received from author(s): April 27, 2012 